\title{
Interneurons and Inhibition in the Dentate Gyrus of the Rat in vivo
}

\author{
Paul S. Buckmaster and Philip A. Schwartzkroin \\ Departments of Neurological Surgery and Physiology/Biophysics, University of Washington, Seattle, Washington 98195
}

Inhibitory cells are critically involved in shaping normal hippocampal function and are thought to be important elements in the development of hippocampal pathologies. However, there is relatively little information about the extent and pattern of axonal arborization of hippocampal interneurons and, therefore, about the sphere of influence of these cells. What we do know about these cells is based largely on in vitro slice studies, in which interneuronal interactions may be severely attenuated. The present study was carried out to provide a more realistic picture of interneuron influence. Intracellular recordings were obtained from dentate interneurons in the intact brain of anesthetized rats, and cells were intracellularly labeled with biocytin. The axonal arbors of two classes of dentate interneurons were traced through the hippocampus; each was found to extend long distances (up to half of the total septotemporal length of the hippocampus) perpendicular to the hippocampal lamellae and to target preferential strata. These results suggest that dentate interneurons have far-reaching effects on target cells in distant hippocampal lamellae. One implication of this finding is that dentate neurons should receive more inhibitory synaptic drive in vivo than in slice preparations, in which many inhibitory axon collaterals are amputated. Synaptic responses to perforant path stimulation were examined in granule cells, mossy cells, and CA3 pyramidal cells in vivo, for comparison with previously published results from hippocampal slice studies. In vivo, all cell types showed excitatory synaptic responses that were brief and limited by robust IPSPs that were larger in amplitude and conductance than responses to comparable stimuli recorded in vitro. This difference could not be explained by a change in the intrinsic physiological properties of the cells in the slice preparation, because those parameters were similar in vivo and in vitro. We conclude that dentate gyrus inhibitory interneurons can affect the excitability of neurons in distant areas of the hippocampus, and that these distant influences cannot be appreciated in conventional in vitro preparations.

[Key words: hippocampus, dentate gyrus, hilus, local circuitry, interneuron, IPSP, in vivo]

\footnotetext{
Received June 7, 1994; accepted July 13, 1994.

We thank Paul Schwartz, Janet Clardy, and Dr. Dennis Kunkel for photographic assistance. This work was carried out under NIH Grants NS 15317 and NS 18895 and was sponsored by the American Epilepsy Society with support from The Milken Family Medical Foundation.

Correspondence should be addressed to Philip A. Schwartzkroin, Ph.D., Department of Neurological Surgery, RI-20, University of Washington, Seattle, WA 98195.

Copyright $(1995$ Society for Neuroscience $0270-6474 / 95 / 150774-16 \$ 05.00 / 0$
}

Dentate interneurons play an important role in normal hippocampal function by inhibiting the activity of granule cells and other dentate neurons. Dentate interneurons also are involved in hippocampal pathology. For example, abnormalities in the GABAergic circuitry of the dentate gyrus has been proposed to underlie hyperexcitability in epileptic Mongolian gerbils (Peterson and Ribak, 1989). A subpopulation of dentate interneurons that colocalized the neuropeptide somatostatin is lost from the hilus in human patients with temporal lobe epilepsy (de Lanerolle et al., 1989). Given the potentially key role of dentate interneurons in normal hippocampal function and in hippocampal pathology, it is important to understand their circuit properties. In particular, we would like to identify the target regions of these axonal projections and the extent of these axonal arbors (i.e., the region within which they can influence neural excitability). Currently, there is little information about the extent of the axonal arbors of dentate interneurons. Golgi techniques that have provided detailed descriptions of dentate interneuron somatic and dendritic morphology (Ramon y Cajal, 1893; Lorente de No, 1934; Amaral, 1978; Ribak and Seress, 1983) do not reliably impregnate axons. Despite this limitation, Struble et al. (1978) used Golgi impregnation to describe the axonal arbors of dentate basket cells; they reported that the axon covered a region $450 \mu \mathrm{m}$ wide (i.e., in the "transverse" dimension) and $1100 \mu \mathrm{m}$ along the septotemporal axis. In addition, a recent intracellular labeling study of dentate interneurons in hippocampal slices has revealed that different interneuron subpopulations preferentially target specific strata (Han et al., 1993); however, in that experiment, the total extent of the axonal arbors could not be determined because axon collaterals were amputated by slicing the hippocampus.

To avoid the limitations of the Golgi technique and the hippocampal slice preparation, we intracellularly labeled dentate interneurons in the intact rat brain and examined their axonal collaterals throughout the extent of the hippocampus. For the two classes of interneurons we examined, the axonal arbor was much more extensive than appreciated in slice studies (especially in the septotemporal axis), suggesting that dentate interneurons influence cells in distant hippocampal lamellae. To test this hypothesis, we examined the synaptic responses to perforant path stimulation of dentate neurons and $\mathrm{CA} 3$ pyramidal cells in the intact brain, and compared these responses to those reported from hippocampal slice experiments. If in the intact brain dentate interneurons inhibit distant cells, then their targets in slice preparations should receive less inhibitory synaptic drive because many of their inhibitory synaptic inputs would be amputated. We found that dentate neurons and CA3 pyramidal cells in the intact brain are more inhibited than in vitro, and that the differences in synaptic responses cannot be explained by alterations in intrinsic cell properties. 


\section{Materials and Methods}

Adult female Sprague-Dawley rats $(n=39)$ were anesthetized $(1.3 \mathrm{~g} / \mathrm{kg}$ urethane, i.p.) and placed in a stereotaxic frame (nose bar $=-3.0 \mathrm{~mm}$ ) on an air table. Cerebrospinal fluid was drained from the cisterna magna to improve stability. A concentric bipolar $250 \mu \mathrm{m}$ diameter stimulating electrode (Rhodes Medical Instruments) was directed toward the angular bundle (4.6 $\mathrm{mm}$ lateral and $7.6 \mathrm{~mm}$ posterior to bregma) to activate perforant path fibers, and a recording electrode was directed toward the dentate gyrus $(2.9 \mathrm{~mm}$ lateral and $4.6 \mathrm{~mm}$ posterior to bregma). Recording electrodes were pulled by a horizontal puller (Sutter Instrument) from borosilicate glass. A field recording electrode (5-15 $\mathrm{M} \Omega, 0.9 \%$ $\mathrm{NaCl}$ ) was used first to localize the granule cell layer and to determine the granule cell population spike threshold. Then a sharp intracellular recording electrode ( $1 \mathrm{~m}$ potassium acetate with 2\% biocytin, 80-250 MS measured in vivo) was lowered toward the dentate gyrus where hilar interneurons, granule cells, mossy cells, and CA3 pyramidal cells were impaled.

Intracellular labeling, tissue processing, and morphological analysis. All electrophysiological data were obtained from morphologically identified cells (Fig. 1). Cells were labeled with 2\% biocytin (Molecular Probes) by passing $300 \mathrm{msec} 0.8-1.8 \mathrm{nA}$ hyperpolarizing or depolarizing current pulses every $600 \mathrm{msec}$ for $5-76 \mathrm{~min}(23 \pm 3 \mathrm{~min}$, mean \pm SEM). At the end of the experiment, the rat was perfused with $4 \mathrm{ml}$ heparinized saline followed by $300 \mathrm{ml}$ of $3.5-4 \%$ paraformaldehyde $(\mathrm{PF})$ in $0.1 \mathrm{M}$ phosphate buffer (PB, pH 7.4). The brain was removed, postfixed overnight, and cryoprotected in 30\% sucrose in PB. The hippocampus was removed, slightly flattened, frozen, and sectioned (60$70 \mu \mathrm{m})$ perpendicular to the septotemporal axis.

Serial sections of the entire hippocampus were mounted on gelatinsubbed slides and processed by the ABC method (Hsu et al., 1981). Endogenous peroxidase was suppressed with $10 \%$ ethanol or methanol and $0.3-1.0 \%$ hydrogen peroxide in PB for $0.5-1 \mathrm{hr}$. Cell membranes were made permeable with $0.3-0.5 \%$ Triton X-100 in PB for $1 \mathrm{hr}$. Sections were exposed to ABC solution (1:150, Vector Laboratories) in PB with $0.01 \%$ Triton X-100 for 2-12 hr. After thorough washing in $\mathrm{PB}$ and Tris buffer (TB, pH 7.6-8.0), sections were preincubated in $0.04 \%$ diaminobenzidine (DAB) and $0.25 \%$ nickel ammonium sulfate in TB for $3 \mathrm{~min}$. Hydrogen peroxide was added to result in a $0.0025 \%$ solution, and sections incubated for $0.5-1.0 \mathrm{hr}$. The reaction was stopped by rinses of distilled water. The tissue was cleared and coverslipped with Eukitt.

Two of the best-labeled hilar interneurons (one aspiny fusiform interneuron and one spiny ovoid interneuron) were reconstructed for quantitative analysis of their axonal plexuses. A drawing tube and a $40 \times$ objective on a microscope (Leitz) were used to make camera lucida drawings of sections containing labeled processes. Two-dimensional (2D) axonal length was measured from the drawings. To determine the distribution of axon collaterals across the strata of the dentate gyrus, $2 \mathrm{D}$ axon lengths were measured in the following regions: hilus; granule cell layer; inner, middle, and outer thirds of the molecular layer; and stratum lacunosum-moleculare of CA1.

Perforant path stimulation and analysis of synaptic responses. The methods used to obtain and analyze intracellular recordings have been described previously (Buckmaster et al., 1993). Briefly, intracellular potentials were recorded with the use of an amplifier with an active bridge circuit (Neuro-data Instruments). Cell activity and responses to stimulation were analyzed initially on line and were stored on videotape (Neuro-data Instruments) and computer (pCLAMP) for off-line analysis. Stimuli, delivered at $0.125 \mathrm{~Hz}$, consisted of $150 \mu \mathrm{sec}$ constant current pulses of $0-5 \mathrm{~mA}$. Stimulation intensities were standardized to the population spike threshold ( $T$ ), facilitating the pooling of data between animals.

Spike threshold to perforant path stimulation was determined at the resting membrane potential by increasing stimulus intensity until an action potential was triggered. EPSP duration was measured from the stimulus artifact to the return of the membrane potential to the prestimulus value. To avoid contamination of the EPSP by a depolarizing IPSP, measurements were made from responses recorded with the membrane potential depolarized by DC holding current to at least $-62 \mathrm{mV}$.

Measurements of fast IPSPs were made at a $20 \mathrm{msec}$ latency after the stimulus artifact; slow IPSPs were measured at a $150 \mathrm{msec}$ latency. IPSP amplitude was measured from the prestimulus membrane potential when the cell was at its resting membrane potential. IPSP reversal potential was determined by altering the membrane potential with $\mathrm{DC}$ holding current to increase the amplitude or reverse the polarity of responses to perforant path stimulation of constant intensity. IPSP amplitude was plotted against membrane potential, and the data were fit with a least squares regression line to determine the IPSP reversal potential. The slow IPSP of CA3 pyramidal cells, mossy cells, and hilar interneurons could not be completely reversed, so the reversal potential reported for those cases was extrapolated from hyperpolarizing responses. IPSP conductance was calculated by subtracting the cell's input conductance at rest from the total conductance (input conductance + IPSP conductance) during the IPSP. Input conductance was determined as the slope of a least squares regression line plotted through an $I-V$ curve, where $I$ is DC holding current and $V$ is the membrane potential before the stimulus. Similarly, conductance during the IPSP was determined as the slope of a least squares regression line through an $I-V$ curve, where $I$ is the DC, holding current and $V$ is the membrane potential during the IPSP (either 20 or $150 \mathrm{msec}$ latency).

Analysis of intrinsic physiology. Resting membrane potential was calculated by subtracting the resting intracellular voltage from the extracellular voltage measured when the electrode was withdrawn from the cell.

Membrane time constant was determined by injecting the cell with $0.2-0.6 \mathrm{nA}, 100 \mathrm{msec}$ hyperpolarizing current pulses and measuring resultant membrane potential deflections. Membrane time constant was defined as the time from the onset of the current pulse to the time the membrane potential reached $(1-1 / \mathrm{e}) \times$ maximum voltage deflection.

Action potential duration was measured as the time between the onset and offset of the action potential. Onset of the action potential was defined as the time when the membrane potential increased rapidly, with a slope $\geq 12 \mathrm{mV} / \mathrm{msec}$. The offset of the action potential was defined as the time when the membrane potential returned to the onset value. Action potential amplitude was measured from the membrane potential at the onset of the spike to its peak. Action potential duration and amplitude were measured from responses to $100 \mathrm{msec}$ depolarizing current pulses just large enough to evoke one action potential.

Input resistance was examined by measuring the maximal membrane potential deflections to $0.2-0.6 \mathrm{nA}, 100 \mathrm{msec}$ hyperpolarizing current pulses, and dividing the membrane potential deflection by the current pulse amplitude.

Burst afterhyperpolarization (burst AHP) was measured in cells that produced at least four action potentials in response to $100 \mathrm{msec}$ depolarizing current injection. Peak amplitude was measured from the resting membrane potential to the peak amplitude of the burst AHP. Burst AHP latency was defined as the time from the offset of the current pulse to the peak amplitude of the burst AHP.

Spike afterhyperpolarizations (spike AHPs) were analyzed by examining responses to small amplitude $100 \mathrm{msec}$ depolarizing current pulses that evoked only one action potential. Spike AHP peak amplitude was measured from the membrane potential at the onset of the action potential to the peak of the spike AHP. Spike AHP latency was defined as the time between the onset of the action potential and the peak of the spike AHP.

Anomalous rectification was recognized by a sag in the membrane potential toward resting membrane potential in response to hyperpolarizing current injection $(300 \mathrm{msec},>0.8 \mathrm{nA})$.

Statistics. Results are expressed as mean \pm SEM. Comparisons between cell types were analyzed with chi-squared test or Students $t$ test (two tailed).

\section{Results}

Morphological and physiological data were obtained from 44 cells: 5 hilar neurons ( 2 aspiny fusiform hilar interneurons and 3 spiny hilar interneurons), 15 granule cells, 13 mossy cells, and 11 CA3 pyramidal cells (9 CA3c, 1 CA3b, 1 CA3a).

\section{Morphology}

Granule cells, mossy cells, and CA3 pyramidal cells were recognized easily by their characteristic morphological features (Fig. 1).

Interneurons were identified by (1) the location of their soma within the hilus, (2) lack of thorny excrescences, and (3) typical interneuron intrinsic physiology (see below). Based on mor- 

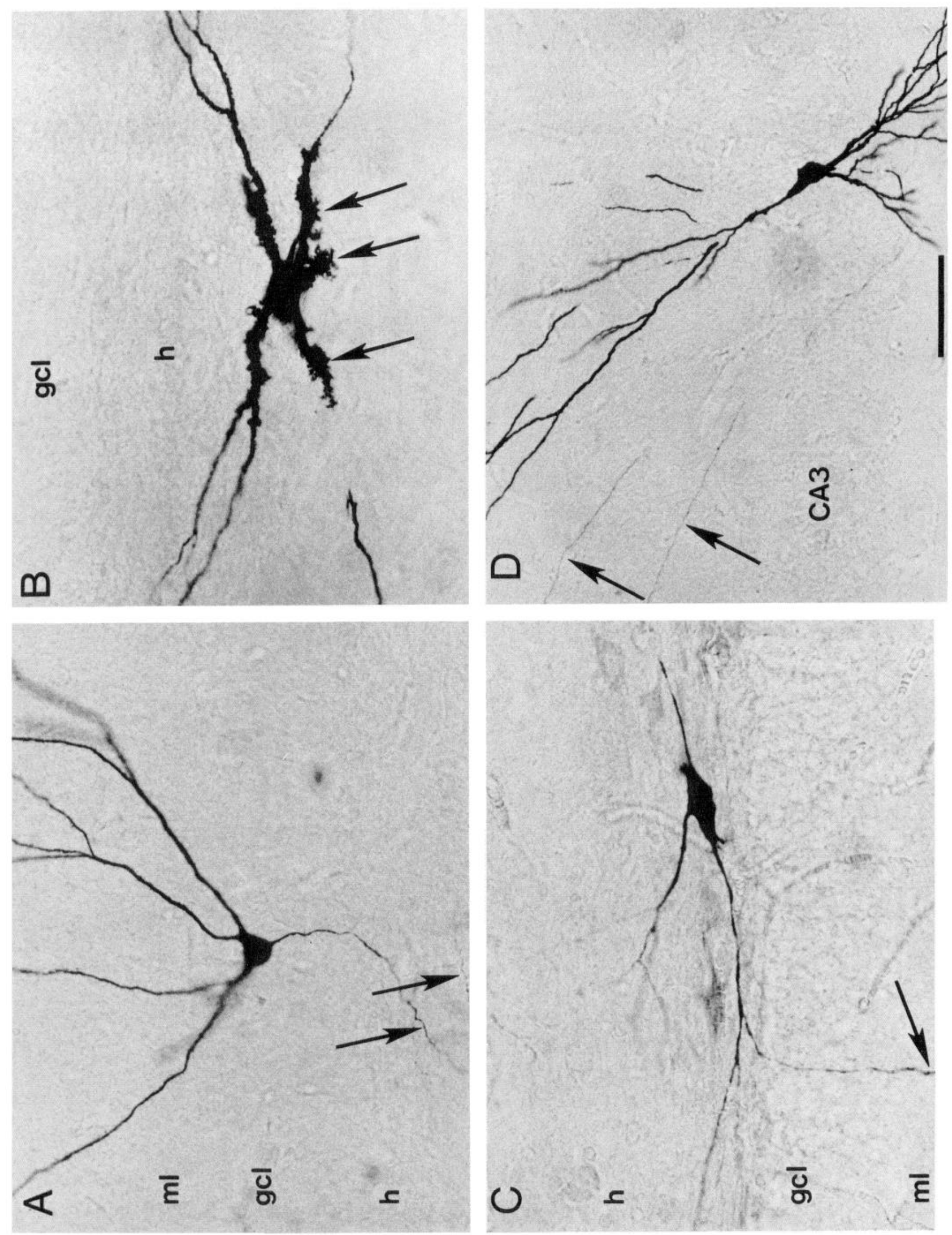
phology, hilar interneurons fell into two groups: aspiny fusiform cells $(n=2)$ and spiny cells $(n=3)$.

\section{Aspiny fusiform cell}

Aspiny fusiform somata were close to the inferior blade of the granule cell layer (12 and $21 \mu \mathrm{m}$ away) (Fig. $1 C$ ). Their aspiny beaded dendrites seldom branched and extended parallel to the granule cell layer in the subgranular region of the hilus like the sparsely spiny fusiform interneuron of Ribak and Seress (1988) and the infrapyramidal fusiform interneuron of Amaral (1978) (described using the Golgi technique). However, the cells in the present study differed from those reported previously in that they were completely aspiny, and they extended one dendrite into the molecular layer of the dentate gyrus.

The best-labeled aspiny fusiform hilar interneuron (Fig. 1C) had a clearly visible axon plexus, permitting the first description of the axonal projection of this cell type (Fig. 2). Its axonal arbor could be followed into 59 of $12060 \mu \mathrm{m}$ thick sections comprising the hippocampus. In other words, this cell had axon collaterals in $49 \%$ of the septotemporal extent of the hippocampus (Fig. 3 ). Axon collaterals were restricted to the dentate gyrus and extended $1.32 \mathrm{~mm}$ ( 22 sections) from the soma toward the temporal pole and $2.22 \mathrm{~mm}$ ( 37 sections) from the soma toward the septal pole. Axon length per section peaked in sections close to the soma where the plexus was most dense, and tapered off relatively symmetrically in sections farther from the soma (Figs. $2,4)$. Forty-six percent $(132 \mathrm{~mm})$ of the total $2 \mathrm{D}$ axon length (291 mm) was within an ideal $400 \mu \mathrm{m}$ thick slice containing the soma (Fig. $4 A$ ). Most ( $88 \%$ ) of the axon length was in the molecular layer; the granule cell layer and hilus contained only $5 \%$ and $7 \%$, respectively (Figs. $4 B, 6$ ). For further analysis of the axon, the molecular layer was divided into three regions (inner, middle, and outer thirds), corresponding to regions of specific afferent input to the dentate gyrus (ipsilateral associational and commissural, medial entorhinal cortical, and lateral entorhinal cortical, respectively) (Blackstad, 1956; Steward, 1976). This interneuron's axon collaterals preferentially targeted the middle molecular layer, which received $62 \%$ of the total molecular layer axon length (Figs. $4 C, 6$ ); the inner and outer molecular layers contained only $28 \%$ and $10 \%$ of the molecular layer axon, respectively. The other aspiny fusiform hilar interneuron in our sample had a similar axon projection pattern.

\section{Spiny hilar cell}

Spiny interneurons were positioned farther from the granule cell layer (i.e., deeper in the hilus); the mean distance from the granulc cell layer was $83 \pm 34 \mu \mathrm{m}$ (range $=31$ to $148 \mu \mathrm{m}$ ). Long simple spines were sparse on the proximal dendrites and more concentrated on the middle and distal parts of the dendrites (Fig. 5B2). The thin dendrites ramified throughout the hilus but were confined therein (Fig. 5BI). These somatic and dendritic features are similar to those of calretinin-immunoreactive hilar neurons (Gulyas et al., 1992; Soriano and Frotscher, 1993), which also have dendrites that do not penetrate the granule cell layer and dendritic spines with small heads and long necks.

The axonal arbor of the best-labeled spiny hilar interneuron extended through $23 \%$ ( 25 of $10770 \mu \mathrm{m}$ thick sections) of the total hippocampal length (Fig. 3). Collaterals projected $910 \mu \mathrm{m}$ (13 sections) from the soma toward the temporal pole and 840 $\mu \mathrm{m}$ (12 sections) from the soma toward the temporal pole. Like the aspiny fusiform cells, the spiny hilar interneurons' axon arbors were densest in sections close to the soma and tapered off symmetrically. Axon collaterals targeted the outer one-third of the molecular layer (Figs. 5A,6), and some could be traced across the hippocampal fissure and into stratum lacunosummoleculare of CAl (Fig. 5A2). The remaining two spiny hilar interneurons in our sample had similar axon projections. Thus, the axon projections of these spiny hilar interneurons resembled somatostatin-immunoreactive hilar neurons whose immunopositive axon plexus concentrates in the outer molecular layer of the dentate gyrus (Bakst et al., 1986; Leranth et al., 1990; Buckmaster et al., 1994). Spiny hilar interneurons with axonal projections to the outer molecular layer have been intracellularly labeled previously in slice experiments (Buckmaster et al., 1993; Han et al., 1993). However, the present study provides the first data describing this cell type's axon arbor in vivo; the septotemporal extent of this cell type's axon projections exceeds previous estimates (see Han et al., 1993).

\section{Synaptic responses}

The extensive axonal arbors of these interneurons suggest that they influence the excitability of neurons in distant hippocampal lamellae. We, therefore, predicted that IPSPs of target cells in vivo should be larger than IPSPs of the same cell types recorded using the slice preparation, because (1) many inhibitory axon collaterals would be amputated during slice preparation, and (2) amputated axons have a reduced ability to release neurotransmitter (Staley and Mody, 1991). To test this hypothesis, in vivo synaptic responses of dentate neurons and CA3 pyramidal cells were examined and compared with in vitro data obtained in our laboratory using comparable stimulation protocols.

\section{Excitatory synaptic responses}

In response to perforant path stimulation, all cells (granule cells, mossy cells, hilar interneurons, and CA3 pyramidal cells) showed a brief ( $\leq 14$ msec duration) EPSP (Table 1). In some cases the EPSP triggered one (rarely two) action potentials. Threshold (T) for spike initiation was measured as a function of stimulus intensity required to drive a just-discernable population spike in the granule cell region. Hilar interneurons had the lowest spike threshold (average $=0.6 \times \mathrm{T}$ ) of the four cell groups, but the spike threshold varied across cells; one hilar interneuron did not discharge an action potential even at high stimulus intensities (up to $3 \times \mathrm{T}$ ). One hilar neuron fired two action potentials at high $(>1.75 \times \mathrm{T})$ stimulus intensities (and at lower stimulus intensities when the membrane potential was depolarized by

Figure 1. Examples of morphologically identified cells. $A$, Granule cell. Axon collaterals (arrows) ramify in the hilus. $B$, Mossy cell. Large, complex spines (thorny excrescences, arrows) cover the proximal dendrites. $C$, Aspiny fusiform hilar interneuron. The fusiform soma is in the subgranular region of the inferior blade of the granule cell layer. Aspiny dendrites extend along the subgranular region and one projects through the granule cell layer and into the molecular layer (arrow). $D$, CA3 pyramidal cell. Schaffer collaterals (arrows) extend toward the CAl field. Abbreviations: $m l=$ molecular layer of the dentate gyrus; $g c l=$ granule cell layer; $h=$ hilus; $C A 3=$ CA3 pyramidal cell layer. Calibration bar (in $D$ ) is $50 \mu \mathrm{m}$ for $A, B$, and $C ; 100 \mu \mathrm{m}$ for $D$. 

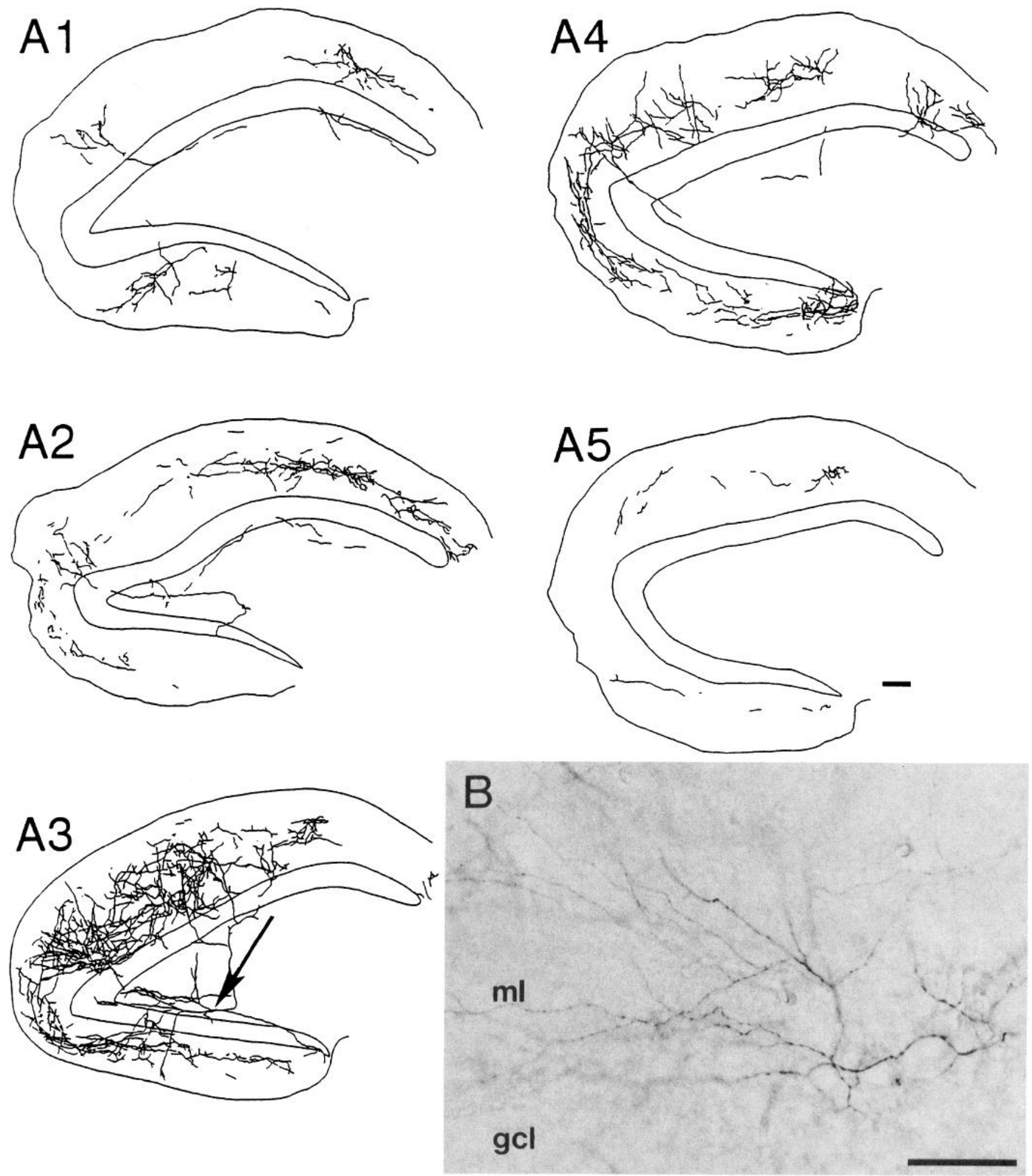

Figure 2. Aspiny fusiform hilar interneuron. A, Camera lucida drawings of the interneuron and its axon in $120 \mu \mathrm{m}$ thick section (two $60 \mu \mathrm{m}$ sections comprise each $120 \mu \mathrm{m}$ section) along the septotemporal axis of the hippocampus. Note the concentration of axon collaterals in the middle one-third of the molecular layer of the dentate gyrus. $A 1,800 \mu \mathrm{m}$ septal from the soma. $A 2,400 \mu \mathrm{m}$ septal from the soma. $A 3$, The soma (arrow) was in the subgranular region of the hilus near the inferior blade of the granule cell layer. The same cell is shown in Figure $1 C$. $A 4,400 \mu \mathrm{m}$ temporal from the soma. $A 5,800 \mu \mathrm{m}$ temporal from the soma. Calibration bar $=100 \mu \mathrm{m}$. B. Photograph of labeled axon collaterals in the molecular layer $(\mathrm{ml})$ and granule cell layer $(\mathrm{gcl})$ in the section containing the soma. Calibration bar $=50 \mu \mathrm{m}$. 
DC current), but none of the interneurons showed complex excitatory responses consisting of compound or prolonged EPSPs or bursts of action potentials. These threshold data are generally consistent with previous reports of dentate interneurons in slices (Scharfman, 1991, 1992b) and recorded extracellularly in vivo (Buzsaki and Eidelberg, 1981, 1982), showing that these cells have lower spike thresholds than granule cells. However, the brief and simple nature of the excitatory response is somewhat in contrast to the burst response that has been described for interneurons in vitro (e.g., Scharfman, 1992b).

CA3 pyramidal cells had the highest spike threshold; even with very high stimulus intensities (up to $13 \times \mathrm{T}$ ), many CA3 cells failed to reach spike threshold. Presumably, this high threshold for CA3 reflects the primarily disynaptic nature of their input from the perforant pathway. In contrast, all mossy cells were effectively driven by perforant path stimulation. Three of the tested mossy cells had dendrites extending into the dentate molecular layer, and their mean spike threshold was lower $(0.5$ $\times \mathrm{T})$ than that of the tested mossy cell without a molecular layer dendrite $(2.0 \times \mathrm{T})$. Consistent with these findings, Scharfman's (1991) slice studies have shown that mossy cells with a dendrite extending into the molecular layer have lower spike thresholds than granule cells, whereas mossy cells with dendrites confined to the hilus have higher spike thresholds.

\section{IPSPS}

Biphasic IPSPs were recorded in all cells tested with perforant path stimulation: 9 granule cells, 10 mossy cells, 4 hilar interneurons, and 9 CA3 pyramidal cells. A summary of the IPSP analysis is shown in Table 1.

Granule cells (Fig. 7A). Large conductance fast and slow IPSPs were recorded in granule cells. At resting membrane potential, the fast IPSP frequently $(3 / 5,60 \%)$ was depolarizing because the cells' resting membrane potential was so hyperpolarized; however, in such cases, the fast IPSP could be reversed easily (Table 1). The polarity of the slow IPSP of granule cells, unlike in other cell types, also could be reversed (Fig. $7 A$, Table 1), and the slow IPSP of granule cells consistently increased in amplitude as the membrane potential was depolarized (mean level of depolarization $=-54 \pm 2 \mathrm{mV}, \mathrm{n}=8$ ).

Hilar Interneurons (Fig. 7B). Hilar interneuron biphasic IPSPs were smaller in amplitude and conductance than IPSPs in the other three cell types (Table 1). Fast and slow IPSP amplitudes in hilar interneurons were significantly $(p<0.05)$ smaller than in CA3 pyramidal cells; the differences from other cell types were not statistically significant. Slow IPSPs were difficult to reverse in hilar interneurons.

Mossy cells (Fig. 8A). Mossy cells had smaller amplitude fast and slow IPSPs than CA 3 pyramidal cells $(p<0.05)$ and smaller conductance slow IPSPs than CA3 pyramidal cells and granule cells (differences not statistically significant). Like CA3 pyramidal cells, mossy cell slow IPSPs showed an anomalous voltage dependency. At membrane potentials more depolarized than -68 to $-51 \mathrm{mV}$ (mean $-59 \mathrm{mV} \pm 3, n=5$ ), the slow IPSP amplitude decreased.

CA3 pyramidal cells (Fig. 8B). CA3 pyramidal cells had large conductance and large amplitude fast and slow IPSPs. With the exception of one cell, the slow IPSP decreased in amplitude at membrane potentials more depolarized than -64 to $-43 \mathrm{mV}$ (mean $-56 \pm 4 \mathrm{mV}, n=5$ ).

These synaptic physiology results show that all of the cell types examined display brief excitatory responses and robust
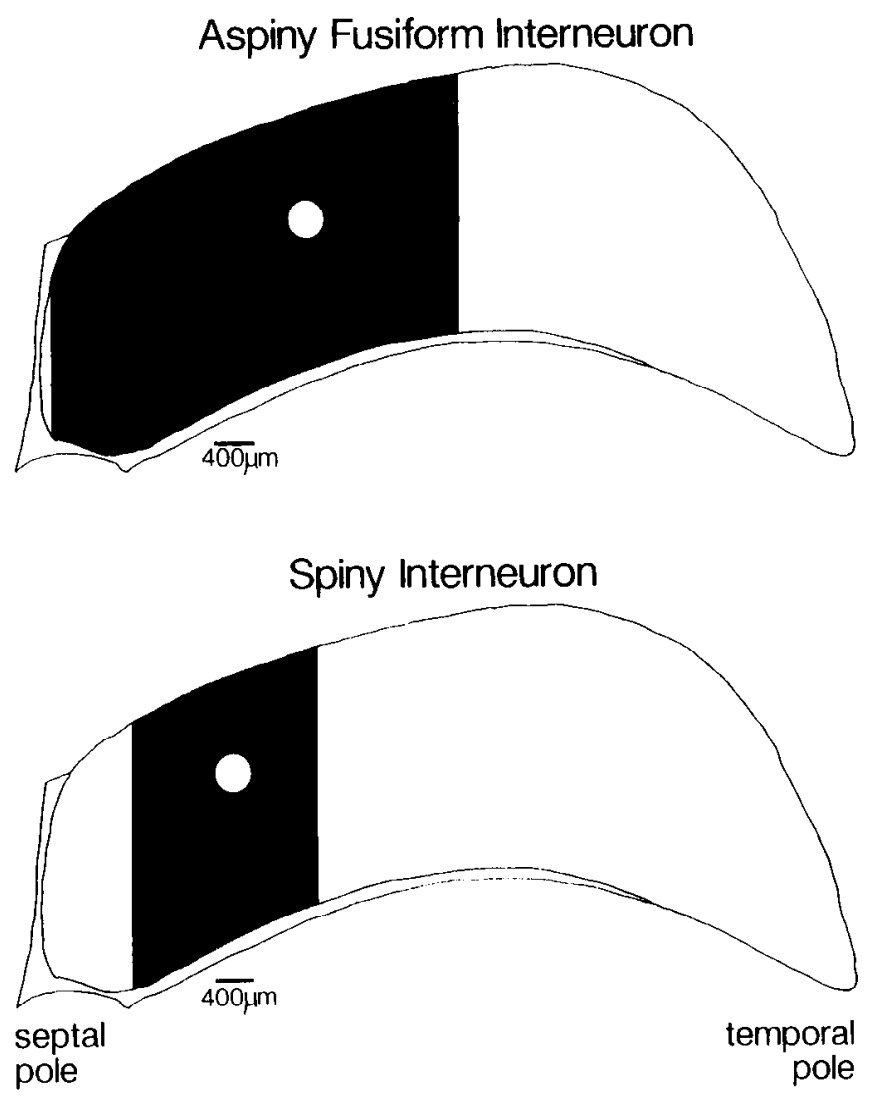

Figure 3. Schematic of hilar interneuron axonal arbor extent in a "flattened" hippocampus. Soma position of an aspiny fusiform hilar interneuron and a spiny hilar interneuron is indicated by the white spot. The septotemporal span of the axon collaterals is indicated by the dark region. The axonal arbors of the aspiny fusiform hilar interneuron and the spiny hilar interneuron spanned $49 \%$ and $23 \%$, respectively, of the septotemporal axis.

biphasic IPSPs in vivo. The EPSPs were briefer and less effective in triggering action potentials than observed in vitro, and IPSPs were generally more prominent. Within the dentate hilus, for example, the mossy cell mean IPSP conductance (early IPSP) was $29 \mathrm{nS}$ in vivo compared to only $12 \mathrm{nS}$ in vitro (Buckmaster et al., 1993).

\section{Intrinsic physiology}

In order to determine whether the differences in synaptic drive, in vivo versus in vitro, were due to differences in intrinsic physiological properties in the slice versus intact animal, intrinsic physiological traits of granule cells, mossy cells, hilar interneurons, and CA3 pyramidal cells were measured (Table 2). The characterization of intrinsic cell properties in vivo revealed no differences from intrinsic physiological data obtained in vitro.

Granule cells (Fig. 9A). Granule cells displayed marked spikefrequency adaptation. The membrane time constant was somewhat longer (not statistically significant) than in hilar interneurons, and was significantly ( $p<0.005$ ) shorter than in mossy cells and CA3 pyramidal cells. The resting membrane potential of granule cells was significantly $(p<0.05)$ more hyperpolarized than all other cell types. Spike AHPs of granule cells were slightly larger (not statistically significant) in amplitude than those of CA3 pyramidal cells and mossy cells.

Mossy cells. Mossy cells tended to discharge a train of action 

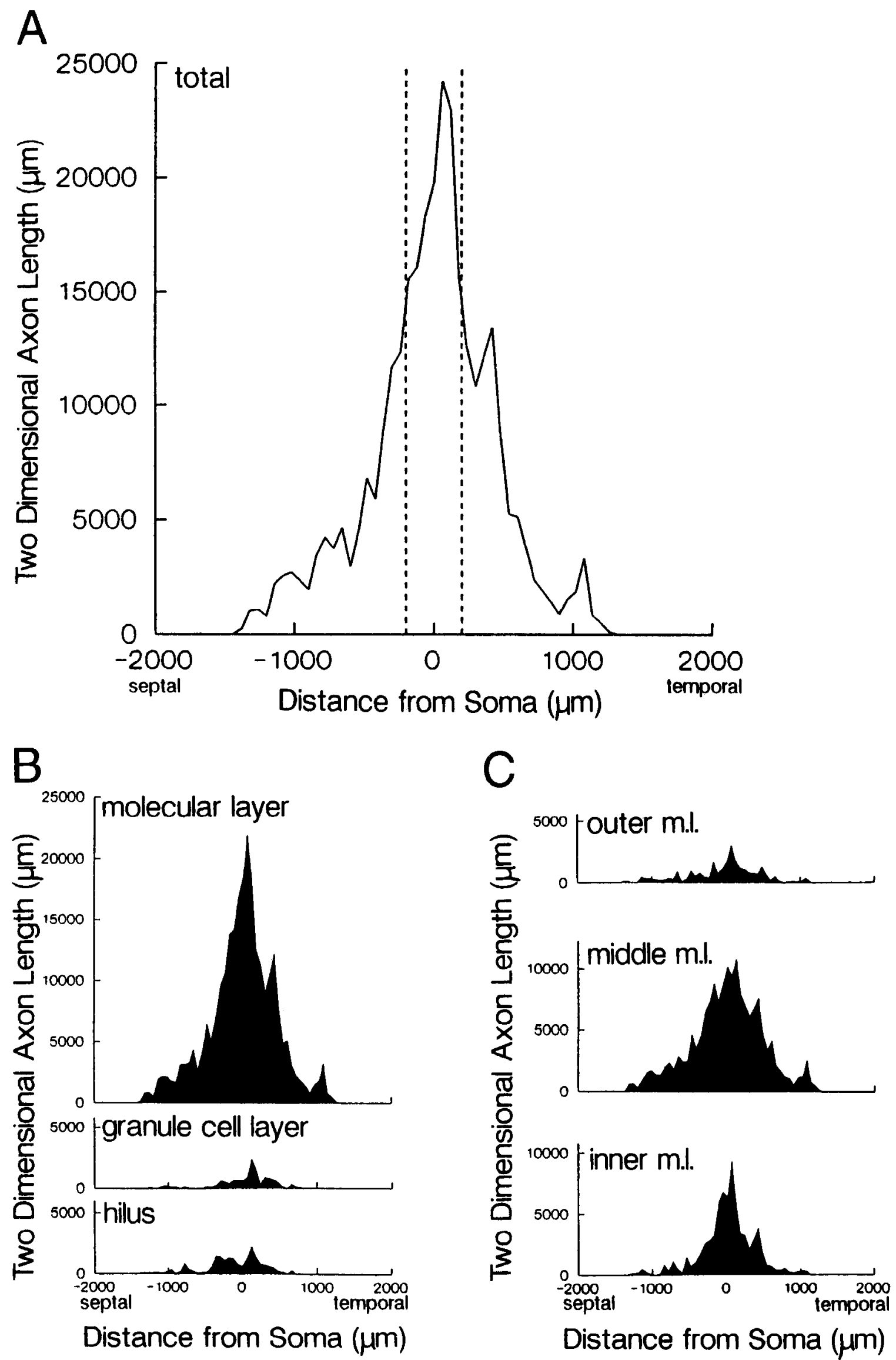

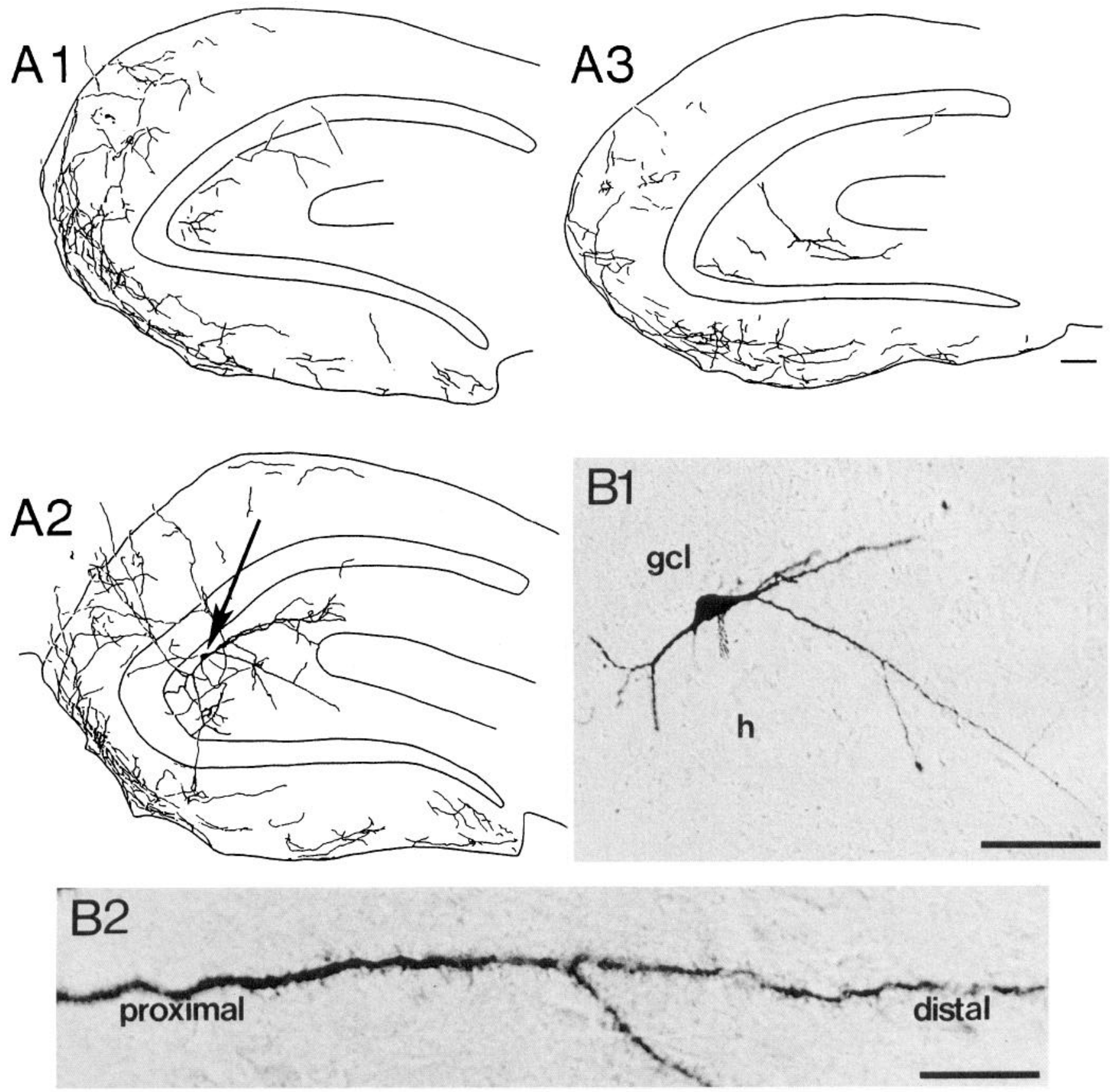

Figure 5. Spiny hilar interneuron. A, Camera lucida drawings of the interneuron and its axon in adjacent $180 \mu \mathrm{m}$ thick sections (three $60 \mu \mathrm{m}$ sections comprise each $180 \mu \mathrm{m}$ section). Note the concentration of axon collaterals in the outer one-third of the molecular layer of the dentate gyrus. A1, Septal from the soma. A2, The soma is in the hilus near the apex of the granule cell layer (arrow). Some axon collaterals crossed the hippocampal fissure and entered stratum lacunosum-moleculare of CA1. $A 3$, Temporal from the soma. Calibration bar $=100 \mu \mathrm{m}$. $B 1$, Dendrites extend throughout the hilus but are confined therein; $g c l=$ granule cell layer, $h=$ hilus. Calibration bar $=100 \mu \mathrm{m}$. B2, Higher magnification of one of the dendrites shown in B1. Many long, simple spines cover the distal dendrite but there are fewer proximally. Calibration bar $=25 \mu \mathrm{m}$.

potentials in response to depolarizing current injection (Fig. $9 B 1)$, although a minority $(4 / 11,36 \%)$ sometimes produced a burst of action potentials. Mossy cells showed only slight spikefrequency adaptation and little, if any, burst AHP (Fig. 9B2).
Most $(10 / 11,91 \%)$ mossy cells showed anomalous rectification in response to hyperpolarizing current injection (Fig. 9B3).

Hilar Interneurons. Hilar interneurons displayed little, if any, spike-frequency adaptation (Fig. 9C2). The membrane time

Figure 4. Two-dimensional axon length vs. distance from the soma of an aspiny fusiform interneuron (same cell shown in Figs. $1 C, 2) . A$, Total axon. Dashed lines indicate the borders of a $400 \mu \mathrm{m}$ thick slice, with the interneuron soma in the middle; only $46 \%$ of the interneuron's total $2 \mathrm{D}$ axon length is contained within the borders of the $400 \mu \mathrm{m}$ thick slice. $B$. Distribution of axon length across hilus, granule cell layer, and molecular layer. $C$, Further breakdown of molecular layer $(m . l$. $)$ axon distribution into inner, middle, and outer thirds; this cell shows a preferential targeting of the middle molecular layer. 


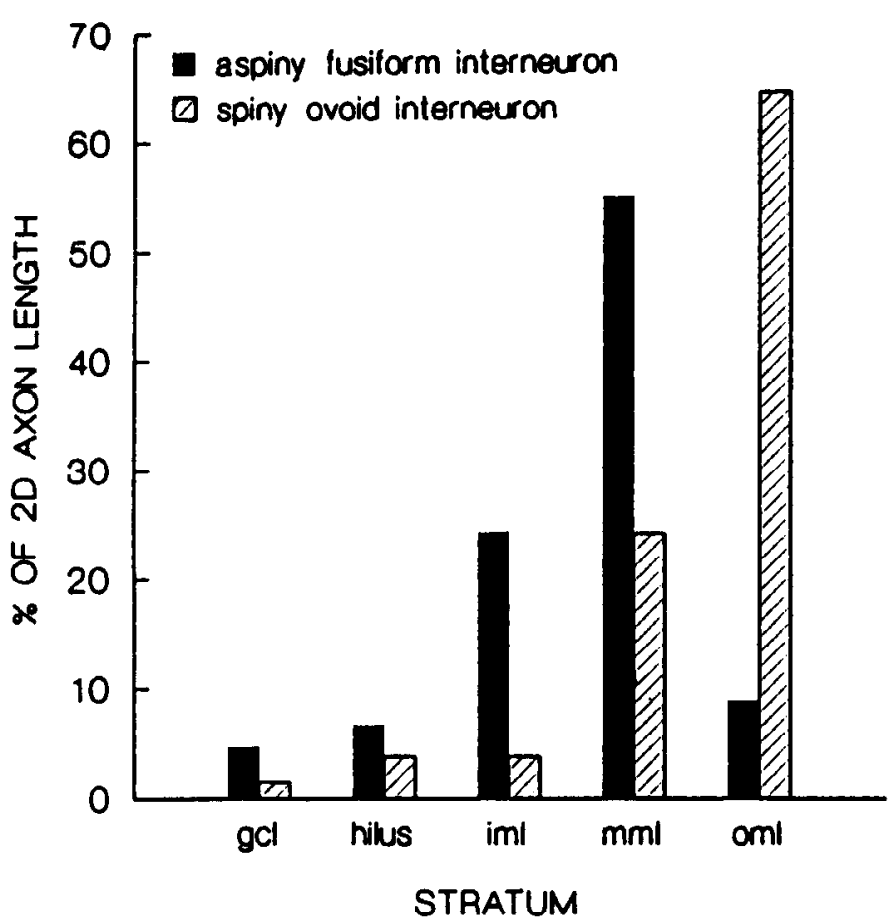

Figure 6. Axonal targets of hilar interneurons. Two-dimensional (2D) axon length in the granule cell layer $(g c l)$; hilus; inner one-third of the molecular layer $(\mathrm{iml})$, middle one-third of the molecular layer $(\mathrm{mml})$, and outer one-third of the molecular layer $(\mathrm{oml})$ of the aspiny fusiform interneuron shown in Figures $1 C$ and 2 and of the spiny interneuron shown in Figure 5 . Note that the aspiny fusiform hilar interneuron's axon concentrates in the middle molecular layer; whereas, the spiny hilar interneuron concentrates in the outer molecular laycr. The spiny interneuron had $2.1 \%$ of its labeled axon length in stratum lacunosummoleculare of CA1. Both interneurons project the majority of their axon into the molecular layer rather than to other strata of the dentate gyrus. constant of hilar interneurons (Fig. $9 C 1$ ) was significantly $(p<$ 0.005 ) shorter than that of mossy cells and CA3 pyramidal cells, but the difference from the granule cell membrane time constant did not reach statistical significance. Hilar interneurons had the shortest duration action potentials of all the cell types $(p<$ 0.05), and they had the most pronounced spike AHPs (Fig. $9 \mathrm{Cl}$ ). Spike AHPs of hilar interneurons were significantly larger in amplitude $(p<0.001)$ and longer in duration (reflected by their significantly longer latency to peak amplitude, $p<0.005$ ) than other cell types.

CA3 pyramidal cells. Most CA3 pyramidal cells $(7 / 8,88 \%)$ responded to depolarizing current injection with a burst of action potentials (Fig. 9DI). CA3 pyramidal cells showed more spike-frequency adaptation than mossy cells and hilar interneurons. Anomalous rectification rarely was observed in CA3 pyramidal cells $(1 / 9,11 \%)$. CA3 pyramidal cells had large amplitude (mean $8 \pm 2 \mathrm{mV}$, range 5 to $11 \mathrm{mV}, n=3$ ), long latency (mean $211 \pm 48 \mathrm{msec}$, range 117 to $277 \mathrm{msec}, n=3$ ) burst AHPs (Fig. 9D2) which were not evident in mossy cells.

\section{Discussion}

The results of this study show that putative inhibitory dentate gyrus interneurons have extensive and region-specific axonal arbors that can influence the excitability of neurons in distant hippocampal lamellae. This hypothesis is supported by the finding of more robust synaptic inhibition in the intact hippocampus versus the in vitro hippocampal slice. The lesser inhibition seen in the slice preparation cannot be explained by an alteration in the intrinsic physiology of dentate neurons receiving input from inhibitory interneurons (cf. published data from slice experiments on granule cells, Brown et al., 1981; Fournier and Crepel, 1984; Fricke and Prince, 1984, mossy cells, Scharfman and Schwartzkroin, 1988; Buckmaster et al., 1993, hilar interneu-

Table 1. Synaptic responses to perforant path stimulation

\begin{tabular}{|c|c|c|c|c|}
\hline & Granule cells & $\begin{array}{l}\text { Hilar } \\
\text { interneurons }\end{array}$ & Mossy cells & $\begin{array}{l}\text { CA3 } \\
\text { Pyramidal cells }\end{array}$ \\
\hline $\begin{array}{l}\text { Stimulus } \\
\text { intensity }(\times \mathrm{T})\end{array}$ & $\begin{array}{l}1.6+0.1 \\
(6)\end{array}$ & $\begin{array}{l}1.6 \pm 0.2 \\
(4)\end{array}$ & $\begin{array}{l}1.6 \pm 0.1 \\
(7)\end{array}$ & $\begin{array}{l}1.6 \pm 0.1 \\
(7)\end{array}$ \\
\hline \multicolumn{5}{|c|}{ Fast IPSP (20 msec latency) } \\
\hline $\begin{array}{l}\text { Reversal } \\
\text { potential (mV) }\end{array}$ & $\begin{array}{l}-69 \pm 1 \\
(6)\end{array}$ & $\begin{array}{l}-68 \pm 12 \\
(2)\end{array}$ & $\begin{array}{l}-68 \pm 2 \\
(6)\end{array}$ & $\begin{array}{l}-69 \pm 1 \\
(4)\end{array}$ \\
\hline Amplitude (mV) & $\begin{array}{l}2(\text { depol. }) \pm 3 \\
(5)\end{array}$ & $\begin{array}{l}3 \pm 2 \\
(3)\end{array}$ & $\begin{array}{l}5 \pm 1 \\
(6)\end{array}$ & $\begin{array}{l}10 \pm 1 \\
(6)\end{array}$ \\
\hline Conductance (nS) & $\begin{array}{l}34 \pm 14 \\
(6)\end{array}$ & $\begin{array}{l}10 \pm 5 \\
(2)\end{array}$ & $\begin{array}{l}29 \pm 9 \\
(6)\end{array}$ & $\begin{array}{l}28 \pm 8 \\
(7)\end{array}$ \\
\hline \multicolumn{5}{|c|}{ Slow IPSP (150 msec latency) } \\
\hline $\begin{array}{l}\text { Reversal } \\
\text { potential (mV) }\end{array}$ & $\begin{array}{l}-101 \pm 6 \\
(6)\end{array}$ & $\begin{array}{l}-108 \\
(1)\end{array}$ & $\begin{array}{l}-103 \pm 5 \\
(6)\end{array}$ & $\begin{array}{l}-115 \pm 8 \\
(4)\end{array}$ \\
\hline Amplitude (mV) & $\begin{array}{l}9 \pm 3 \\
(5)\end{array}$ & $\begin{array}{l}7 \pm 1 \\
(3)\end{array}$ & $\begin{array}{l}7 \pm 2 \\
(6)\end{array}$ & $\begin{array}{l}15 \pm 2 \\
(6)\end{array}$ \\
\hline Conductance (nS) & $\begin{array}{l}10 \pm 4 \\
(6)\end{array}$ & $\begin{array}{l}4 \\
(1)\end{array}$ & $\begin{array}{l}4 \pm 1 \\
(7)\end{array}$ & $\begin{array}{l}12 \pm 8 \\
(6)\end{array}$ \\
\hline \multicolumn{5}{|l|}{ EPSP } \\
\hline Duration (msec) & $\begin{array}{l}12 \pm 1 \\
(6)\end{array}$ & $\begin{array}{l}13 \pm 2 \\
(4)\end{array}$ & $\begin{array}{l}14 \pm 1 \\
(7)\end{array}$ & $\begin{array}{l}11 \pm 1 \\
(7)\end{array}$ \\
\hline
\end{tabular}



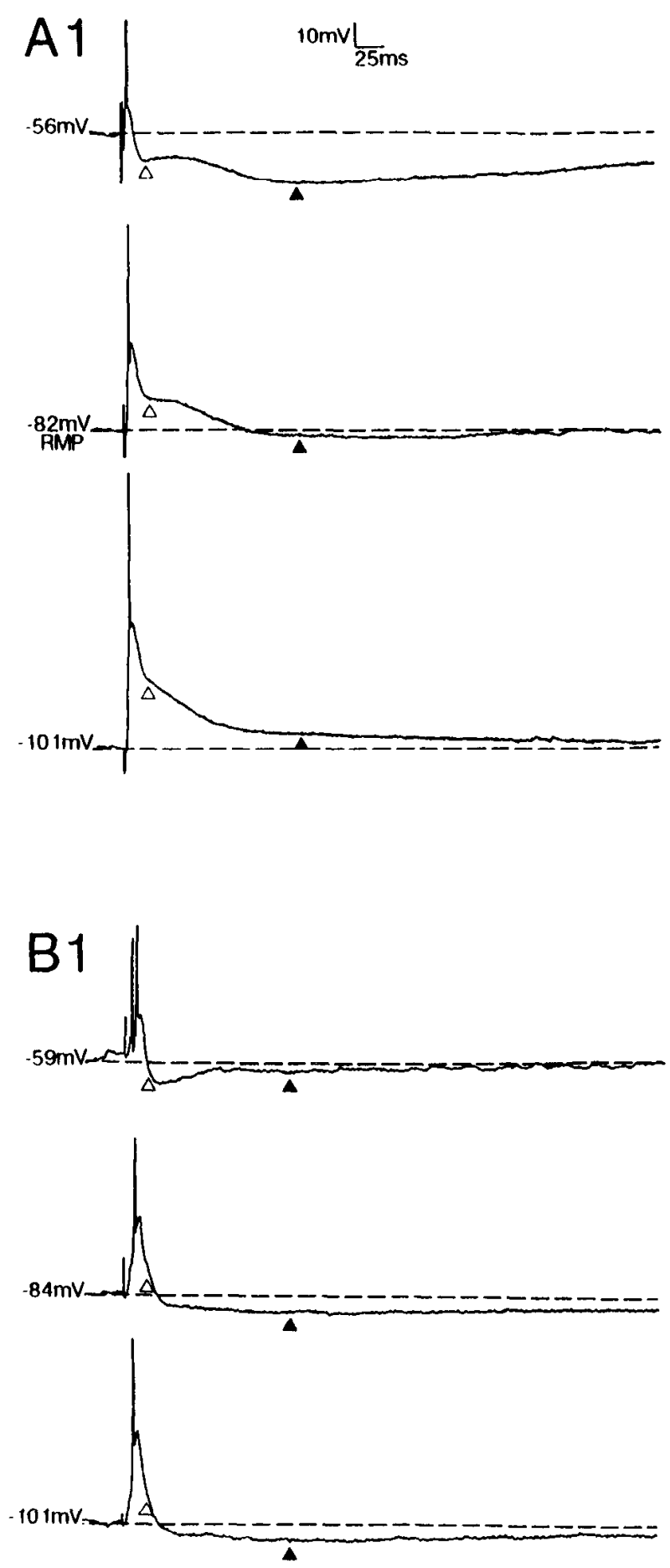

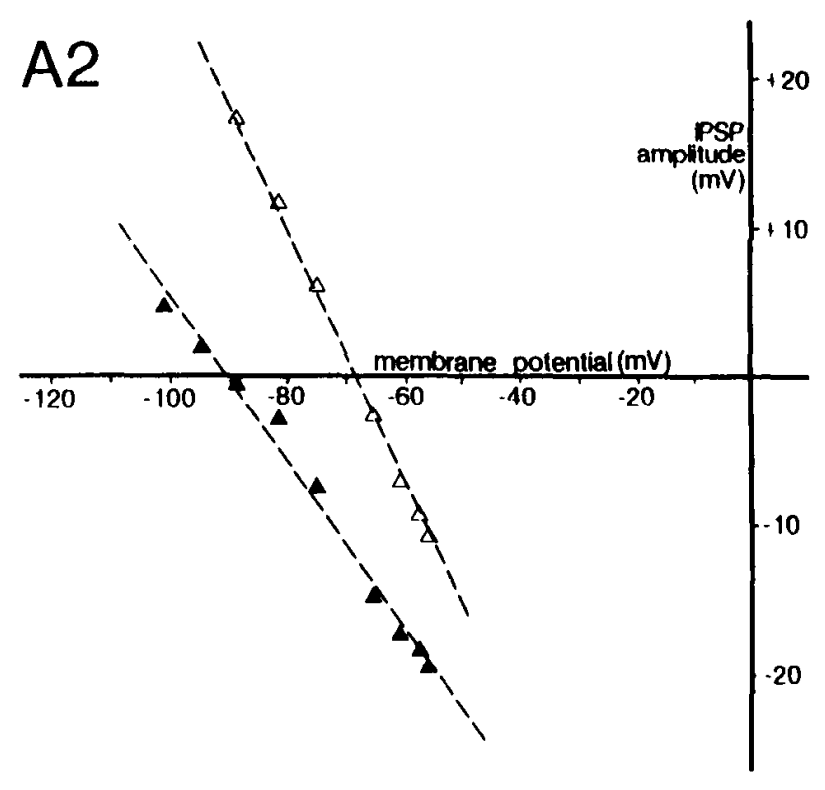

A3

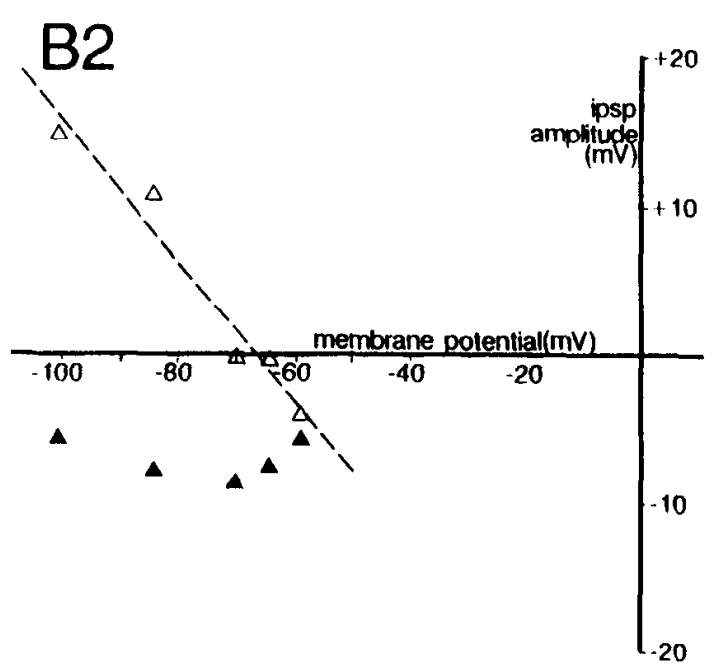

Figure 7. Synaptic responses of a granule cell and a hilar interneuron to perforant path stimulation. A, Granule cell. A1, Perforant path stimulation $(2.8 \times \mathrm{T})$ evoked a brief EPSP that triggered one action potential followed by a biphasic IPSP. The fast IPSP was depolarizing and the slow IPSP amplitude was small at the hyperpolarized resting membrane potential $(R M P)$. The slow IPSP reversed at membrane potentials more hyperpolarized than $-90 \mathrm{mV}$. A2, Plot of fast (20 msec latency, open triangles) and slow (150 msec latency, filled triangles) IPSP amplitude versus membrane potential. The reversal potential of the fast IPSP was $-68 \mathrm{mV}$; the slow IPSP reversal potential was $-90 \mathrm{mV}$. $A 3$, Extracellular field response recorded after withdrawing the electrode out of the cell. $B$, Aspiny fusiform hilar interneuron. $B 1$, Perforant path stimulation $(0.5 \times \mathrm{T})$ evoked two action potentials (at depolarized membrane potentials) followed by a biphasic IPSP. This was the only cell in our entire sample that discharged more than one action potential in response to perforant path stimulation. There was no extracellular response available for this cell. $B 2$, The fast IPSP reversed at $-67 \mathrm{mV}$; the slow IPSP did not have a clear reversal potential. 
Table 2. Intrinsic physiology

\begin{tabular}{|c|c|c|c|c|}
\hline & Granule cells & $\begin{array}{l}\text { Hilar } \\
\text { interneurons }\end{array}$ & Mossy cells & $\begin{array}{l}\mathrm{CA} 3 \\
\text { Pyramidal cells } \\
\end{array}$ \\
\hline $\begin{array}{l}\text { Resting membrane } \\
\text { potential }(\mathrm{mV})\end{array}$ & $\begin{array}{l}-71 \pm 2 \\
-60 \text { to }-86 \\
13\end{array}$ & $\begin{array}{l}-61 \pm 2 \\
-58 \text { to }-65 \\
3\end{array}$ & $\begin{array}{l}-59 \pm 2 \\
-55 \text { to }-64 \\
9\end{array}$ & $\begin{array}{l}-64 \pm 2 \\
-57 \text { to }-77 \\
10\end{array}$ \\
\hline Input resistance $(\mathrm{M} \Omega)$ & $\begin{array}{l}79 \pm 10 \\
31 \text { to } 147 \\
12\end{array}$ & $\begin{array}{l}59 \pm 10 \\
45 \text { to } 99 \\
5\end{array}$ & $\begin{array}{l}88 \pm 9 \\
49 \text { to } 123 \\
10\end{array}$ & $\begin{array}{l}75 \pm 6 \\
45 \text { to } 118 \\
10\end{array}$ \\
\hline $\begin{array}{l}\text { Action potential } \\
\text { amplitude }(\mathrm{mV})\end{array}$ & $\begin{array}{l}60 \pm 3 \\
45 \text { to } 78 \\
10\end{array}$ & $\begin{array}{l}56 \pm 4 \\
46 \text { to } 68 \\
5\end{array}$ & $\begin{array}{l}55 \pm 3 \\
39 \text { to } 69 \\
10\end{array}$ & $\begin{array}{l}57 \pm 3 \\
44 \text { to } 66 \\
7\end{array}$ \\
\hline $\begin{array}{l}\text { Spike AHP } \\
\text { amplitude }(\mathrm{mV})\end{array}$ & $\begin{array}{l}6.7 \pm 0.9 \\
1.5 \text { to } 10.4 \\
10\end{array}$ & $\begin{array}{l}14.7 \pm 1.1 \\
11.0 \text { to } 17.0 \\
5\end{array}$ & $\begin{array}{l}5.2 \pm 0.6 \\
3.6 \text { to } 8.6 \\
9\end{array}$ & $\begin{array}{l}5.0 \pm 0.9 \\
2.0 \text { to } 9.5 \\
7\end{array}$ \\
\hline $\begin{array}{l}\text { Spike AHP latency } \\
\text { to peak (msec) }\end{array}$ & $\begin{array}{l}2.9 \pm 0.2 \\
2.0 \text { to } 3.9 \\
10\end{array}$ & $\begin{array}{l}5.5 \pm 0.4 \\
4.7 \text { to } 7.0 \\
5\end{array}$ & $\begin{array}{l}3.5 \pm 0.2 \\
2.9 \text { to } 4.2 \\
9\end{array}$ & $\begin{array}{l}3.1 \pm 0.2 \\
2.5 \text { to } 3.7 \\
7\end{array}$ \\
\hline
\end{tabular}

Values represent mean \pm SEM, range, and $n$.

rons, Scharfman, 1992b, and CA3 pyramidal cells, Brown et al., 1981; Buckmaster et al., 1993), and, therefore, may reflect the loss/truncation of inhibitory interneuron arborization within the slice.

\section{Hilar interneurons}

Aspiny fusiform hilar interneurons. This study provides the first description of the axonal projections of the fusiform hilar interneuron. The extent of its axonal ramifications was impressive, projecting to hippocampal lamellae over $1 \mathrm{~mm}$ distant from the soma and surpassing lengths reported for other hippocampal interneuron types (Struble et al., 1978; Li et al., 1992). In rat, this extent of axon ramification corresponds to about $50 \%$ of the entire hippocampal length. Despite the extensive septotemporal projection of this cell, it appeared to be a true local circuit neuron, since its axonal arbor was densest in the region near the soma and did not extend beyond the confines of the dentate gyrus. Axon collaterals concentrated in the middle one-third of the molecular layer, where granule cell dendrites receive afferent input from the medial entorhinal cortex (Steward, 1976). These findings suggest that a given aspiny fusiform hilar interneuron preferentially inhibits the effects of medial entorhinal cortical input to both nearby and distant granule cells.

Spiny hilar interneurons. The spiny hilar interneurons described in this study should not be confused with "spiny hilar neurons," a term that has been used (e.g., Scharfman, 1992b) to refer to mossy cells, and not to inhibitory interneurons. The morphological features of the spiny hilar interneurons resemble subsets of previously described somatostatin (Bakst et al., 1986;
Lcranth et al., 1990; Buckmaster et al., 1994) and calretinin immunoreactive hilar neurons (Gulyas et al., 1992; Soriano and Frotscher, 1993) whose dendrites are confined to the dentate hilus. This similarity suggests that there might be a subpopulation of hilar interneurons that colocalize the neuropeptide and the calcium binding protein. This speculation is consistent with the findings that in the hilus, somatostatin (Johansen et al., 1987) and calretinin immunoreactivity (Freund and Magloczky, 1993) both disappear early after forebrain ischemia before CAl pyramidal cells die. It has been suggested that the death of the inhibitory spiny hilar interneurons precedes and contributes to CA1 pyramidal cell death (Freund and Magloczky, 1993; Hsu and Buzsaki, 1993). The results of the present study and others (Han et al., 1993) show that some of the axon collaterals of spiny hilar interneurons project into $\mathrm{CAl}$ where they normally might inhibit CAl pyramidal cells. Loss of this inhibitory input might play a role in disinhibition of CA1 after ischemia. These cells, too, extend axon arbors that cover a significant proportion of the hippocampus; although less extensive than the aspiny fusiform cell, the axon arbor far exceeds the dimension of a hippocampal slice.

The two types of hilar interneurons labeled in this study both sent their axons into the molecular layer of the dentate gyrus. However, within the molecular layer, each cell type targeted different regions. These findings are consistent with immunocytochemical evidence for stratification of interneuron axon collaterals (e.g., Sloviter and Nilaver, 1987) and with cell-labeling slice experiments that show axon target specificity of dentate interneurons. Han et al. (1993) have recently described dentate 

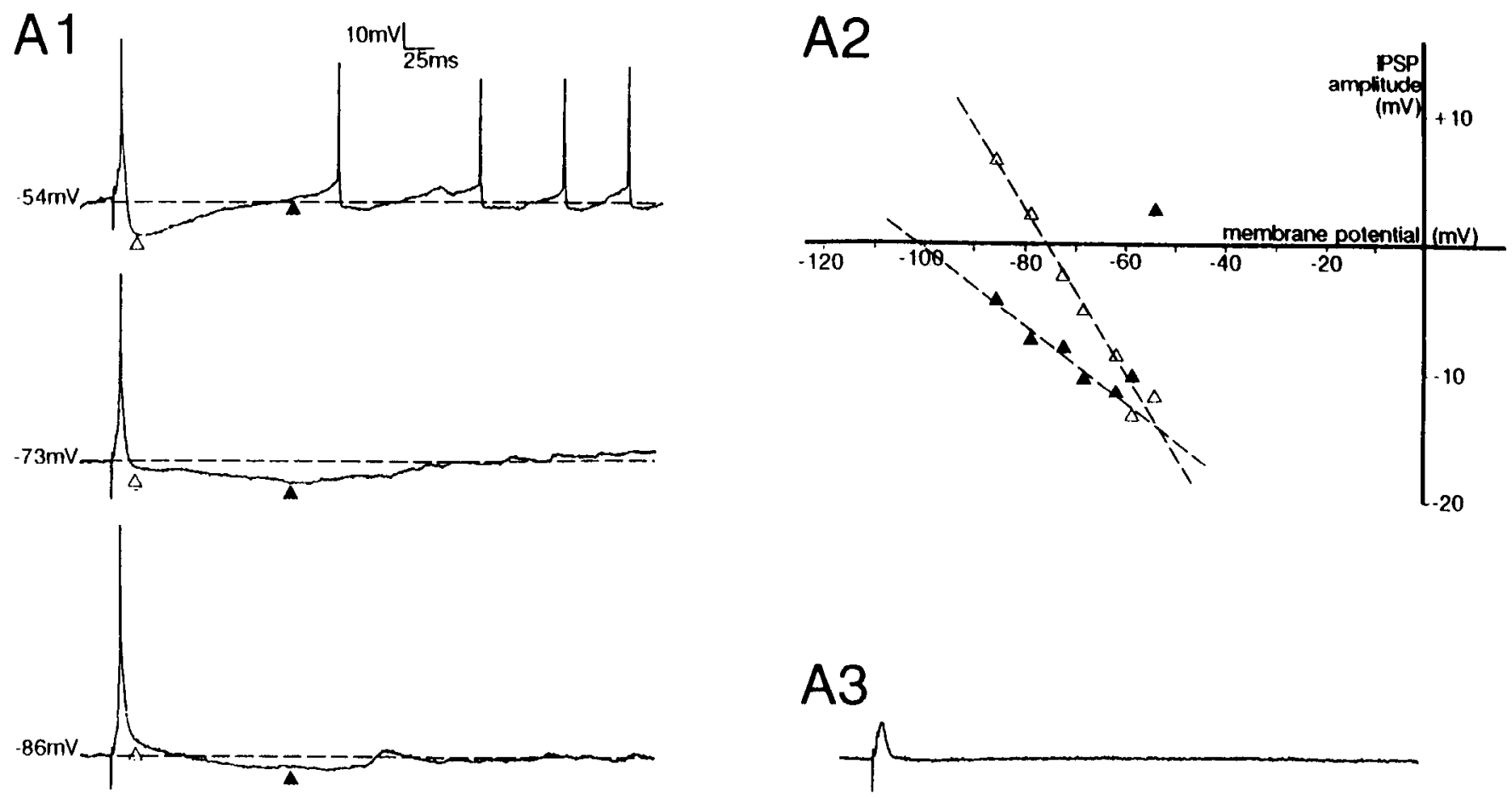

\section{A3}

B1
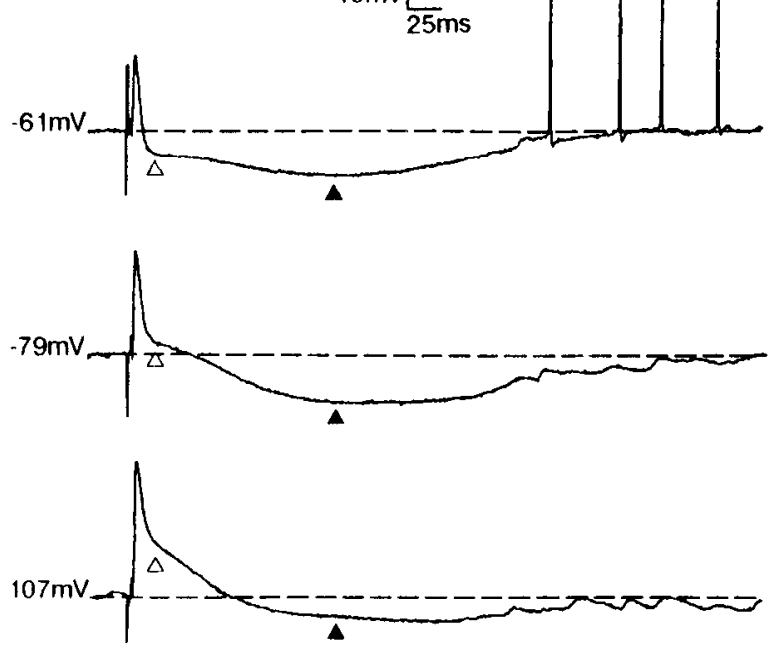

B2

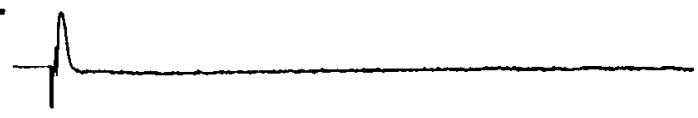

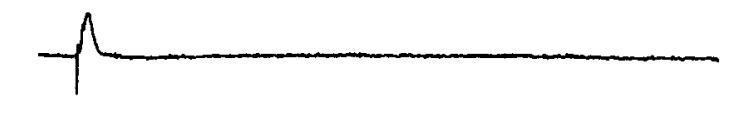

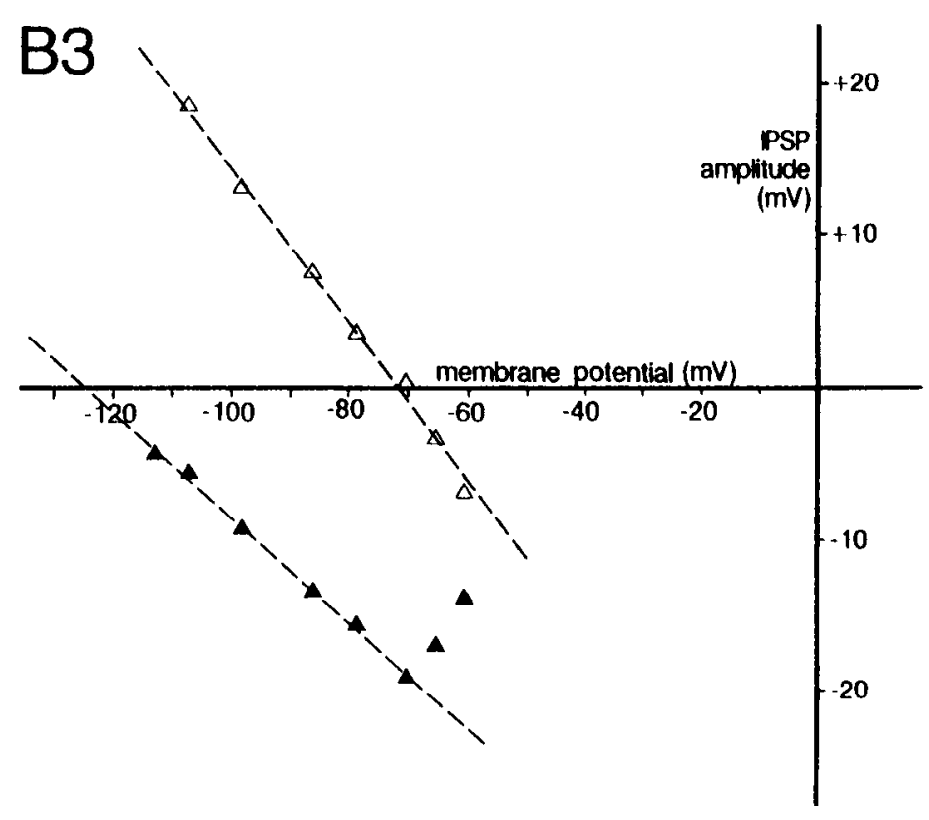

Figure 8. Synaptic responses of a mossy cell and a CA3 pyramidal cell to perforant path stimulation. $A$, Mossy cell. $A 1$, Perforant path stimulation $(2.5 \times \mathrm{T})$ evoked a brief EPSP that triggered an action potential followed by a biphasic IPSP. The slow IPSP amplitude decreased at depolarized membrane potentials and was not completely reversed at hyperpolarized membrane potentials. A2, Plot of fast (20 msec latency, open triangles) and slow (150 msec latency, flled triangles) IPSP amplitude versus membrane potential. The reversal potential of the fast IPSP was - $75 \mathrm{mV}$; the extrapolated slow IPSP reversal potential was $-101 \mathrm{mV} . A 3$, Extracellular field response recorded after withdrawing the electrode out of the cell. $B$, CA3c pyramidal cell. BI. Perforant path stimulation $(3.8 \times \mathrm{T})$ evoked a brief EPSP (no action potential) followed by a large amplitude biphasic IPSP. The slow IPSP amplitude decreased at depolarized membrane potentials and was not completely reversed at hyperpolarized membrane potentials. B2, Extracellular field response recorded after withdrawing the electrode from the cell. B3, Plot of fast and slow IPSP amplitude versus membrane potential. The reversal potential of the fast IPSP was $-72 \mathrm{mV}$; the extrapolated slow IPSP reversal potential was $-125 \mathrm{mV}$. 

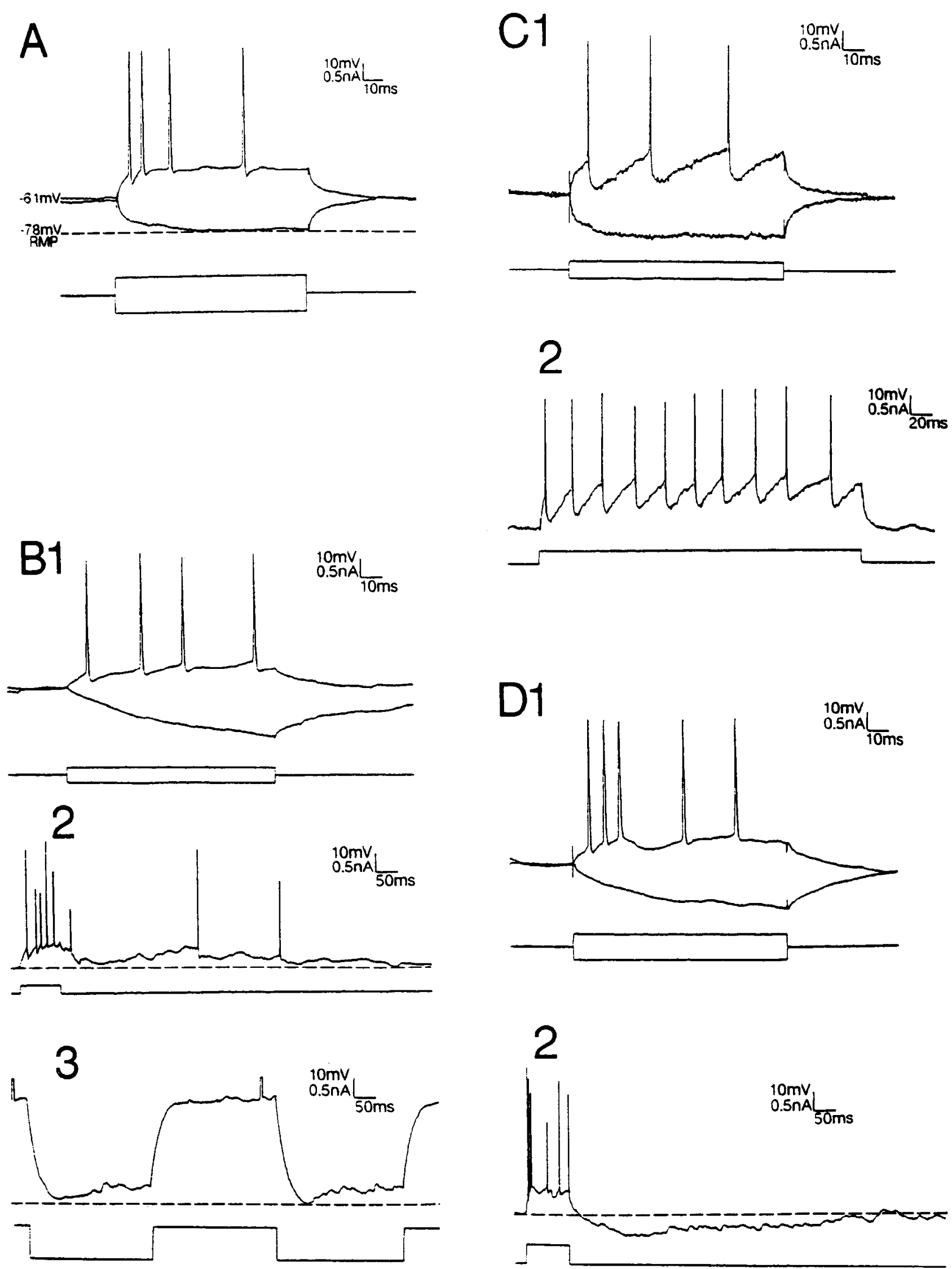

Figure 9. Intrinsic physiology of dentate gyrus neurons and CA3 pyramidal cells recorded in vivo. A, Granule cell with a hyperpolarized resting membrane potential $(R M P)$, fast membrane time constant, and spike-frequency adaptation. $B$, Mossy cell showing little spike-frequency adaptation, a long membrane time constant $(B 1)$, and no burst afterhyperpolarization $(A H P)(B 2)$. Spikes have been truncated by digitization. $B 3$, Anomalous rectification frequently was identified in mossy cells by a sag in the membrane potential towards the resting potential after the maximum voltage 
interneurons that specifically target either granule cell axon initial segments, granule cell somata, the inner molecular layer, or the outer molecular layer. We describe, in this study, hilar interneurons that target either the middle molecular layer or the outer molecular layer. Taken together, such studies suggest that distinct interneuron populations may be responsible for selective inhibition at each level of the cell axis: the axon initial segment, the soma, and the inner, middle, and outer thirds of the dendrites.

\section{Synaptic excitability and inhibition in vivo}

In general, it was more difficult to activate spike firing in nongranule cells in vivo than in vitro. Since "threshold" was normalized to the dentate population spike, it is difficult to explain this result simply in terms of technical details, e.g., absolute stimulus intensities and stimulating electrode placement. We hypothesize that these threshold observations are a direct result of relatively greater inhibition in vivo.

In vivo, excitatory synaptic responses appeared to be powerfully curtailed by strong synaptic inhibition. EPSPs were brief, and typically only one (or no) action potentials were evoked, even at high stimulus intensities. In contrast, similar stimulation in vitro elicits bursts of action potentials in mossy cells and hilar interneurons (Scharfman, 1992b). Although several factors could contribute to this in vivo-in vitro difference in excitability, one major contributing factor is likely to be the better preservation of synaptic inhibition in vivo. Indeed, IPSPs were larger in vivo than has been reported for orthodromically elicited IPSPs of dentate and CA3 neurons in hippocampal slice preparations (Thalmann and Ayala, 1982; Knowles et al., 1984; Buckmaster et al., 1993). All cell types examined in vivo showed robust, biphasic IPSPs.

What underlies the apparent reduced inhibition of the hippocampal slice preparation compared to the intact rat brain? Several possibilities exist. First, the anesthetic urethane may enhance the amplitude and conductance of IPSPs. There is little information concerning the mechanism of action of urethane. It is, however, the anesthetic of choice for many acute in vivo epilepsy-related experiments, because it does not interfere with seizure activity (Sloviter, 1983). On the contrary, it has been reported that hippocampal interneurons reduce their discharge rate by up to $50 \%$ in the presence of urethane (Buzsaki et al., 1983). This urethane action appears to be in contrast to barbiturates, which enhance and prolong hippocampal IPSPs (Nicoll et al., 1975). The possibility that urethane might enhance the IPSPs of neurons in the intact brain has not becn ruled out, but current data suggest that its effects would more likely reduce inhibitory effects.

Second, inhibitory interneurons might be selectively vulnerable to the slicing technique, such that slices contain a smaller proportion of viable inhibitory interneurons. It has been reported that hippocampal interneurons are especially sensitive to ischemia and hypoxia (Johansen et al., 1987; Crain et al.,
1988; Hsu and Buzsaki, 1993; Freund and Magloczky, 1993), and tissue almost certainly becomes somewhat ischemic/hypoxic during the slicing procedure. Yet many laboratories have used in vitro techniques to obtain intracellular recordings from hilar interneurons (e.g., Misgeld and Frotscher, 1986; Scharfman et al., 1990; Michelson and Wong, 1991; Livsey and Vicini, 1992; Buckmaster et al., 1993; Han et al., 1993), and the reported intrinsic physiology of interneurons recorded in slices is similar to our results recorded in vivo. Clearly, there is a population of viable interneurons remaining in the dentate hilus of hippocampal slices; the question of whether there is a reduction in the number of viable interneurons in slices has yet to be addressed.

Third, many inhibitory axon collaterals projecting across the hippocampus are severed when the tissue is sliced. The results of this study show that over half of the total axon length of a given aspiny fusiform hilar interneuron is amputated when a $400 \mu \mathrm{m}$ thick slice is prepared. This estimate undoubtedly underestimates the damage because (1) tissue shrinks during processing such that a $400 \mu \mathrm{m}$ thick slice of processed tissue represents a considerably thicker slice of fresh tissue; (2) collaterals that loop outside and then back into the slice are included in the in vivo analysis but would have been functionally disconnected from their soma in a slice; and (3) our in vitro estimate assumes that the interneuron's position is in the middle of the slice-cells closer to the surface would have more axon amputated because of the high density of axon close to the soma. Previous studies have shown that amputation of axon collaterals during slice preparation reduces neurotransmitter release in the dentate gyrus (Staley and Mody, 1991). Therefore, it is likely that the reduced synaptic inhibition of hippocampal slices is due, in large part, to amputation of axon collaterals from inhibitory interneurons whose somata are located in distant lamellae.

The importance of this truncation of inhibitory circuitry in vitro is well illustrated by focusing on current studies of hilar mossy cells. Hippocampal slice experiments have shown that mossy cells receive strong excitatory synaptic input but little inhibitory input (Scharfman and Schwartzkroin, 1988; Livesy and Vicini, 1992; Scharfman, 1992a; Buckmaster et al., 1993). On that basis, investigators have proposed that the extreme vulnerability of mossy cells to brain trauma may result, at least in part, from the weak inhibitory modulation of mossy cell excitability (e.g., Buckmaster et al., 1993). However, recent reports indicate that mossy cells recorded in vivo (Soltesz et al., 1993) receive significant inhibitory synaptic input; inhibitory currents can also be recorded under special conditions in the slice (Soltesz and Mody, 1994), even when IPSPs are not easily evoked. The results of the present study are consistent with all of these previous findings; the evoked IPSP conductance of mossy cells recorded in vivo is much larger than the IPSP conductance recorded in vitro. We propose that axon amputation and the consequent dysfunction of inhibitory axon collaterals explains the lesser evoked inhibition in slices.

deflection (dashed line) in response to hyperpolarizing current pulses. $C$, Hilar interneuron. $C l$, Fast action potentials were followed by pronounced spike AHPs. The membrane time constant was short. $C 2$, Little or no spike-frequency adaptation. $D$, CA3 pyramidal cell discharged a burst of action potentials in response to depolarizing current injection and showed spike-frequency adaptation, a long membrane time constant (DI), and a large amplitude, long lasting burst AHP (D2). 


\section{Implications and conclusions}

The results of this study provide new data on the inhibitory circuitry of the dentate gyrus, showing that dentate interneurons have relatively specific and extensive axonal projections. The relative laminar specificily of the axonal projections suggests that different subpopulations of dentate interneurons could affect dentate excitability in a target-specific manner. Further, the extent of inhibition is impressively widespread; loss of inhibitory interneurons even in a restricted area of the dentate region (è.g., in epileptic "foci") may have significant consequences for excitability over much of the hippocampus.

\section{References}

Amaral DG (1978) A Golgi study of cell types in the hilar region of the hippocampus in the rat. J Comp Neurol 182:851-914.

Bakst I, Avendano C, Morrison JH, Amaral DG (1986) An experimental analysis of the origins of somatostatin-like immunoreactivity in the dentate gyrus of the rat. J Neurosci $6: 1452-1462$.

Blackstad TW (1956) Commissural connections of the hippocampal region in the rat, with special reference to their mode of termination. J Comp Neurol 105:417-537.

Brown TH, Fricke RA, Perkel DH (1981) Passive electrical constants in three classes of hippocampal neurons. J Neurophysiol 46:812-827.

Buckmaster PS, Strowbridge BW, Schwartzkroin PA (1993) A comparison of rat hippocampal mossy cells and CA3c pyramidal cells. J Neurophysiol 70:1281-1299.

Buckmaster PS, Kunkel DD, Robbins RJ, Schwartzkroin PA (1994) Somatostatin-immunoreactivity in the hippocampus of mouse, rat, guinea pig, and rabbit. Hippocampus 4:167-180.

Buzsaki G, Eidclbcrg E (1981) Commissural projection to the dentate gyrus of the rat: evidence for feed-forward inhibition. Brain Res 230: 346-362.

Buzsaki G, Eidelberg E (1982) Direct afferent excitation and long-term potentiation of hippocampal interneurons. J Neurophysiol 48:597607.

Buzsaki G, Leung L-W S, Vanderwolf CH (1983) Cellular basis of hippocampal EEG in the behaving rat. Brain Res Rev 6:139-171.

Crain BJ, Westerkam WD, Harrison AH, Nadler JV (1988) Selective neuronal death after transient forebrain ischemia in the Mongolian gerbil: a silver impregnation study. Neuroscience 27:387-402.

de Lanerolle NC, Kim JH, Robbins. RJ, Spencer DD (1989) Hippocampal interneuron loss and plasticity in human temporal lobe epilepsy. Brain Res 495:387-395.

Fournicr E, Crepel F (1984) Elcctrophysiological propertics of dentate granule cells in mouse hippocampal slices maintained in vitro. Brain Res 311:75-86.

Freund TF, Magloczky ZS (1993) Early degeneration of calretinincontaining neurons in the rat hippocampus after ischemia. Neuroscience 56:581-596.

Fricke RA, Prince DA (1984) Electrophysiology of dentate gyrus granule cells. J Neurophysiol 51:195-209.

Gulyas AI, Miettinen R, Jacobowitz DM, Freund TF (1992) Calretinin is present in non-pyramidal cells of the rat hippocampus-I. A new type of neuron specifically associated with the mossy fibre system. Neuroscience 48:1-27.

Han Z-S, Buhl EH, Lorinczi Z, Somogyi P (1993) A high degree of spatial selectivity in the axonal and dendritic domains of physiologically identified local-circuit neurons in the dentate gyrus of the rat hippocampus. Eur J Neurosci 5:395-410.

Hsu I, Buzsaki G (1993) Vulnerability of mossy fiber targets in the rat hippocampus to forebrain ischemia. J Neurosci 13:3964-3979.

Hsu S-M, Raine L, Fanger H (1981) Use of avidin-biotin-peroxidase complex (ABC) in immunoperoxidase techniques: a comparison between $\mathrm{ABC}$ and unlabeled antibody (PAP) procedures. J Histochem Cytochem 29:577-580.

Johansen FF, Zimmer J, Diemer NH (1987) Early loss of somatostatin neurons in dentate hilus after cerebral ischemia in the rat precedes CA-1 pyramidal cell loss. Acta Neuropathol (Berl) 73:110-114.

Knowles WD, Schneiderman JH, Wheal HW, Stafstrom CE, Schwartz- kroin PA (1984) Hyperpolarizing potentials in guinea pig hippocampal CA3 neurons. Cell Mol Neurobiol 4:207-230.

Leranth C, Malcolm AJ, Frotscher (1990) Afferent and efferent synaptic connections of somatostatin-immunorcactive neurons in the rat fascia dentata. J Comp Neurol 295:111-122.

Li X-G, Somogyi P, Tepper JM, Buzsaki G (1992) Axonal and dendritic arborization of an intracellularly labeled chandelier cell in the CAl region of rat hippocampus. Exp Brain Res 90:519-525.

Livsey CT, Vicini S (1992) Slower spontaneous excitatory postsynaptic currents in spiny versus aspiny hilar neurons. Neuron 8:745-755.

Lorente de No R (1934) Studies on the structure of the cerebral cortex. II. Continuation of the study of the ammonic system. J Psychol Neurol Leipzig 46:113-177.

Michelson HB, Wong RKS (1991) Excitatory synaptic responses mediated by GABA $_{\mathrm{A}}$ receptors in the hippocampus. Science 253:14201423.

Misgeld U, Frotscher M (1986) Postsynaptic GABAergic inhibition of non-pyramidal ncurons in the guinca-pig hippocampus. Neuroscience 19:193-206.

Nicoll RA, Eccles JC, Oshima T, Rubia F (1975) Prolongation of hippocampal inhibitory postsynaptic potentials by barbiturates. Nature 258:625-627.

Peterson GM, Ribak CE (1989) Relationship of the hippocampal GABAergic system and genetic epilepsy in the seizure-sensitive gerbil. In: The hippocampus - new vistas (Kohler C, Chan-Palay V, eds), pp 483-497. New York: Liss.

Ramon y Cajal S (1968) The structure of Ammon's horn (Kraft LM, trans). Springfield, IL: Thomas (original publication 1893).

Rihak CE, Seress I. (1983) Five types of basket cell in the hippocampal dentate gyrus: a combined Golgi and electron microscopic study. J Neurocytol 12:577-597.

Ribak CE, Seress L (1988) $\wedge$ Golgi-electron microscopic study of the fusiform neurons in the hilar region of the dentate gyrus. J Comp Neurol 271:67-78.

Scharfman HE (1991) Dentate hilar cells with dendrites in the molecular layer have lower thresholds for synaptic activation by perforant path than granule cells. J Neurosci 14:835-857.

Scharfman HE (1992a) Blockade of excitation reveals inhibition of dentate spiny hilar neurons recorded in rat hippocampal slices. $\mathbf{J}$ Neurophysiol 68:978-984.

Scharfman HE (1992b) Differentiation of rat dentate neurons by morphology and electrophysiology in hippocampal slices: granule cells, spiny hilar cells and aspiny 'fast-spiking' cells. Epilepsy Res [Suppl] 7:93-109.

Scharfman HE, Schwartzkroin PA (1988) Electrophysiology of morphologically identified mossy cells of the dentate hilus recorded in guinea pig hippocampal slices. J Neurosci 8:3812-3821.

Scharfman HE, Kunkel DD, Schwartzkroin PA (1990) Synaptic connections of dentate granule cells and hilar neurons: results of paired intracellular recordings and intracellular horseradish peroxidase injections. Neuroscience 37:693-707.

Sloviter RS (1983) "Epileptic" brain damage in rats induced by sustained electrical stimulation of the perforant path. I. Acute electrophysiological and light microscopic studics. Brain Res Bull 10:675697.

Sloviter RS, Nilaver G (1987) Immunocytochemical localization of GABA-, cholecystokinin-, vasoactive intestinal polypeptide-, and somatostatin-like immunoreactivity in the area dentata and hippocampus of the rat. J Comp Neurol 256:42-60.

Soltesz I, Mody I (1994) Patch-clamp recordings reveal powerful GABAergic inhibition in dentate hilar neurons. J Neurosci 14:23652376.

Soltesz I, Bourassa J, Deschenes M (1993) The behavior of mossy cells of the rat dentate gyrus during theta oscillations in vivo. Neuroscience 57:555-564.

Soriano E, Frotscher M (1993) Spiny nonpyramidal neurons in the CA3 region of the rat hippocampus are glutamate-like immunoreactive and receive convergent mossy fiber input. J Comp Neurol 332: 435-448.

Staley KJ, Mody I (1991) Integrity of perforant path fibers and the frequency of action potential independent excitatory and inhibitory synaptic events in dentate gyrus granule cells. Synapse 9:219-224.

Steward O (1976) Topographic organization of the projections from 
the entorhinal area to the hippocampal formation in the rat. J Comp Neurol 167:285-314.

Struble RG, Desmond NL, Levy WB (1978) Anatomical evidence for intralamellar inhibition in the fascia dentata. Brain Res 152:580-585.
Thalmann RH, Ayala GF (1982) A late increase in potassium conductance follows synaptic stimulation of granule neurons of the dentate gyrus. Neurosci Lett 29:243-248. 